\title{
Down-regulation of SOCS3 gene in hypothalamus attenuates diet-induced obesity in young rats
}

\author{
Jie Bian, li Zhang, xuemei Bai, Yongli Zhao ${ }^{*}$, Zhengjuan Liu \\ From 7th APPES Biennial Scientific Meeting \\ Nusa Dua, Bali. 14-17 November 2012
}

\begin{abstract}
Aims
Acquired childhood obesity is becoming increasingly apparent with the changes in children`s life-style and eating environment, which become a severe social and medical problem. Our previous studies have found that the leptin concentrations were high in obese children, supporting that leptin resistance is a main mechanism of childhood obesity. The suppressor of cytokine signaling 3 (SOCS3) is a negative-feedback regulator of leptin signaling involved in leptin resistance, therefore suppression of SOCS3 is a potential therapy for leptin-resistance in obesity. In the studies, we investigate whether hypothalamic silencing of SOCS3 would attenuate diet-induced obesity and leptin resistance in young rats.

\section{Methods}

We first established hypothalamic SOCS3-deficient rats through lentiviral vector mediated RNA interference technique. The LVs expressing SOCS3-shRNA or control-shRNA were injected bilaterally into the arcuate nucleus (ARC) of five-week-old male rats, then provided a high-fat diet (HFD) to the rats. The body weight was measured weekly. After 8 weeks of the diet, the rats were killed, the serum leptin and insulin concentrations were measured by RIA, and the expressions of SOCS3 in ARC were detected by immunohistochemistry and a real time RT-PCR.
\end{abstract}

\section{Results}

The immunostaining showed that LV-SOCS3-shRNA inhibited SOCS3 protein expression and the RNAi protocol knocked down the expression of SOCS3 mRNA by $49 \%$ compared to the controls. The rats with hypothalamic SOCS3 knockdown exhibited significant decrease in body

The Second Hospital Affiliated to Dalian Medical University, China weight gain and lower concentrations of leptin, insulin, glucose and triglyceride when exposed to the HFD.

\section{Conclusion}

Our results provide evidence that rats with hypothalamic SOCS3 silencing are significantly protected against development of diet-induced obesity and SOCS3 is a potential target molecule for therapeutic intervention of obesity.

Published: 3 October 2013

doi:10.1186/1687-9856-2013-S1-046

Cite this article as: Bian et al:: Down-regulation of SOCS3 gene in

hypothalamus attenuates diet-induced obesity in young rats.

International Journal of Pediatric Endocrinology 2013 2013(Suppl 1):046.

Submit your next manuscript to BioMed Central and take full advantage of:

- Convenient online submission

- Thorough peer review

- No space constraints or color figure charges

- Immediate publication on acceptance

- Inclusion in PubMed, CAS, Scopus and Google Scholar

- Research which is freely available for redistribution
C 2013 Bian et al; licensee BioMed Central Ltd. This is an Open Access article distributed under the terms of the Creative Commons Attribution License (http://creativecommons.org/licenses/by/2.0), which permits unrestricted use, distribution, and reproduction in any medium, provided the original work is properly cited. 